\title{
Stake Holders' Perceptions in a Campus Recruitment Process
}

\author{
Dr. R. Prabhakara Raya \\ Head, Department of Management Studies, Pondicherry University, Pondicherry, India \\ Email:drrpraya@gmail.com \\ Dr. V.Samuel Rajkumar \\ Director(Placement and Training), VIT University, Vellore, Tamil Nadu, India \\ Email:sam.rajkumar@vit.ac.in \\ Dr. P. Ganesan \\ Professor, VIT Business School, VIT University, Vellore, Tamil Nadu, India \\ Email: pganesan@vit.ac.in \\ Dr. S.K.V. Jayakumar \\ Placement Co ordinator, Pondicherry University, Pondicherry, India \\ Email: skvjey@gmail.com
}

Doi:10.5901/mjss.2015.v6n5p96

\section{Abstract}

Campus recruitment is a job selection process in which the Industry visits the educational institutions to hire students. In India, the majority of the fresh graduates hiring happens through campus recruitments. The study captures perceptions of the HR1 managers and students on some of the components in a campus recruitment process. It tried to correlate the perceptions of the students and HR managers on Dream company offer, slot sharing, choice of a company, preparation for the recruitment process and the timing of the campus recruitment process. Other specific feedback from HR managers on the expectations from the students and the students' expectations from the industry also was captured. This would enable the industry and the institution to align their recruitment strategies. For the students, it would help in understanding the requirements of the industry in a campus recruitment process.

Keywords: Campus recruitment, slot sharing

\section{Introduction}

Campus recruitment is considered to be a significant factor for both the educational institutions and corporate.

The major advantages of the campus recruitments are cost effectiveness, time saving and also lead to building the brand. Some of the companies that have tried off - campus or just in time hiring have not succeeded in the past because of the uncertainties in the process. In an off campus placement process, there is no certainty of the selected students joining the company. Even though it is the same case with the on campus recruitments, the level of uncertainty is less. The other challenges included the lack of communication, written and analytical skills, which is reported in the NASSCOM ${ }^{2}$ employability report (2011). These challenges can be overcome if the institutions and industry work together to bridge the gap.

Companies are finding a need to strategize and tide over certain difficulties to gain entry into premium institutions of higher learning for campus recruitment. This is due to the war for talent. There is a competition among various organizations to have access to recruit from the campus on the Day $1^{3}$. Usually, on this day most preferred employers as

\footnotetext{
1 Human resources

2 National association of software and services companies

${ }^{3}$ Day 1 is a colloquial term used in the educational institutions to describe the first day of placements. It's prized and reserved for most admired companies
} 
chosen jointly by students, placement cell and management of the institution are invited to conduct their day-long selection process. Sometimes, in certain campuses, students vote to decide which company is invited to college on Day 1. A new trend that is emerging in campus recruitment is slot sharing ${ }^{4}$. This adds a new dimension and additional pressure on both institutions and companies. Be it voting or choosing between two or among three companies, student exercises his or her discretion based on the perception he/she has formed about a company through what he or she makes of a company from his/her seniors, friends or relatives as well as from the company's presentation on-campus introducing the various facets and aspects of the company to the students. To a large extent, these perceptions are driven by the company's brand. It is in their own interest therefore that the company takes branding seriously.

Most of the premier educational institutions in India allow students to take multiple job offers through a concept called "Dream Offer". A student who gets selected in an IT ${ }^{5}$ services company is allowed to take another job offer with another company which offers a higher salary package or that belongs to a core engineering sector. The perceptions of the students and the HR managers on taking a dream offer or timing of the selection process may differ. In this context, an attempt is made in this empirical research to examine the following objectives: (a) to study the perceptions of the students and the HR managers on the campus recruitment process and (b) to examine the perception difference between the students and HR managers on the campus recruitment process.

\subsection{Concept of slot sharing}

Educational institution's campus placements follow a hierarchical order where top firms are given the day one slot (which is the first day for the recruitment season) and the rest follow during the campus placement season. Major campus recruiters vie the top slots during the campus placements season. Universities and colleges have to miss out on some of the recruiters as they could not allot preferred slots to all the major recruiters. Of late, Universities and colleges have started to share the premium slots with the major recruiters. This process of accommodating two or more campus recruiters in a placement slot is called "slot sharing".

Slot sharing is a concept in campus placements where multiple companies share a slot and the student is allowed to attend more than one company. The student selects the company, if selected in more than one. The hiring by software services companies is significant because they select big numbers from the campus. Major recruiters in India like Accenture, $\mathrm{TCS}^{6}$, Cognizant, Wipro, Infosys have always insisted on visiting first to a campus to make sure they get as many good students possible to select given their mass-requirement. In campus placement parlance, SLOT 1 refers to first recruitment day given to a major recruiting software services company and so on. An educational institution had to balance the expectations of companies from software services sector who have mass-hiring requirements. It is almost impossible to give one recruiter a SLOT 1 and convince another to consider SLOT 2.

\section{Literature Survey}

Students' perceptions on campus recruitment process that were captured in the earlier literature vary with time and conditions (context). This effectively meant that the key parameters that qualify a brand change from time to time. Campus placements and industry engagements are among those that are considered important features in an educational system. An educational institution has to attract the industry for ensuring placements to its students and academic/research engagements with its faculty.

In order to be able to do this, it needs to identify the factors that will enable from a branding perspective. Companies have to brand themselves to attract the good students from the campuses. Though in quantity terms the student talent supply is seen to be large in India (given the number of those who pursue their education at the tertiary level), employability of the majority students graduating is seen to be less than ideal. NASSCOM report (2011) says that only 25 per cent of the students who graduate in India have the required employability skills. So, despite the student-base seeming to be large, the companies are forced to target top students belonging to 25 per cent employable segment. This is another cause for companies' focus to brand amongst students.

The studies (Ruth R Robbins, 1996) that were conducted in 1990s showed that compensation offered by the software companies and the size of the company were considered as the most impacting factors for students in selecting

\footnotetext{
${ }^{4}$ Slot sharing is a concept in campus placements where multiple companies share a slot and the student is allowed to attend more than one company. The student selects the company, if selected in more than one.

${ }^{5}$ Information Technology

6 Tata consultancy services
} 
the companies. Other factors like motivation, growth prospects, work environment etc., were secondary. The organizations have to accomplish their reputation to make the job seeker's interested in them. Daniel M. Cable and Mary E. Graham (2000) in their study report that if the organization is able to manage its attributes, it may be able to come closer to the perceptions of the job seekers. In their study they used verbal protocol analysis to analyse the factors that a job seeker would consider in evaluating the organisation's reputation.

Bottjen Audrey and Cohen Andy (2001) suggest that building relationship is the key factor in campus recruiting. Offering student internships, connecting with the students through their alumni, academic interactions with the faculty etc., increase the visibility of the company on campus. In the same vein, James Bailey et al., (2002) report that the corporate should project its right image on the campuses. The corporate should aim for long term relationship with the campuses. This can be not only achieved by formal interactions, but also by organizing social networking meetings between the students, faculty and the corporate executives.

Over the years, the students have preferred $\mathrm{MNCs}^{7}$ over small and medium enterprises to begin their careers. The perceptions of the students (Jane W. Moy and Sze M. Lee, 2002) and the benefits offered by the MNCs have made the $\mathrm{SMES}^{8}$ as second choice for the graduating students. Even in the Indian context, working for an MNC gives a brand image for the students also. MNCs build their reputation and image among their stake holders through various initiatives on campus and through media.

Christopher J. Collins and Cynthia Kay Stevens (2002) through their research suggested that the pre placement or branding activities done for the engineering students by the recruiting companies would have more influence on the career choice of the students. These firms by communicating their job profiles and company profile would have a strategic advantage over their competitors in attracting the best talent for their organizations.

Earlier studies showed that the requirements in a campus recruitment process varied with the sector (Clarke, 2008). Software services companies gave more importance to the soft skills (Gokuladas, 2010) during the campus recruitment process compared to the core engineering sector which emphasised more on the hard skills. Hard skills are related to the academics and soft skills deal with the behavioural aspects.

\section{Methodology}

The study attempted to capture the perceptions of students and HR managers in some of the components of campus recruitment who are considered to be the stake holders in the campus recruitment process. Hence, the descriptive research is employed. Final year students of a Deemed University located in India and the HR managers from software and core engineering companies located in various parts of India were chosen for study. Based on the literature survey an instrument was developed which was empirically tested and a pilot study was also done. Simple random sampling method was used and a total of 1299 final year students were selected for survey, out of which, 697 responses were chosen for the study. Similarly, 86 HR managers who had visited the institution for the recruitments in the earlier years were chosen for the survey. 65 responses were chosen for the study. The questionnaire also had open ended questions to capture the perception of the HR managers on the expected skill sets of the students.

After coding and validation, statistical tools like frequencies and ANOVA were used to test the perceptional difference between the students and HR managers.

\section{Analysis of Stake Holders' Perceptions}

A set of questions were administered in both the studies (institutional branding and employer branding) to capture the perceptions of the HR managers and the students relating to campus recruitment components which included the preparation for placements, slot sharing and timing of the selection process. The components were analysed based on the frequencies, and ANOVA. The results are presented below.

\subsection{Analysis based on the frequencies}

The table 4.1 presents the level of agreement of students in the recruitment process and preparation for campus recruitments.

\footnotetext{
${ }^{7}$ Multinational company

${ }^{8}$ Small and medium sized enterprises
} 
Table 4.1 Level of agreement of students on campus recruitment process

\begin{tabular}{|l|c|c|c|c|c|c|}
\hline Question & Strongly agree & Agree & Neutral & Disagree & $\begin{array}{c}\text { Strongly } \\
\text { disagree }\end{array}$ & $\begin{array}{c}\text { Mean (Standard } \\
\text { deviation) }\end{array}$ \\
\hline Having multiple companies to share the slot gives a & 216 & 298 & 128 & 41 & 14 & 2.051 \\
student to select his/her career of choice & $(31)$ & $(42)$ & $(18.4)$ & $(5.9)$ & $(2)$ & $(0.953)$ \\
\hline I would choose a company after doing my own research & 134 & 287 & 211 & 51 & 14 & 2.317 \\
or homework & $(19.2)$ & $(41.2)$ & $(30.3)$ & $(7.3)$ & $(2)$ & $(0.932)$ \\
\hline It is better to have campus placements in last semester & 151 & 192 & 176 & 130 & 48 & 2.615 \\
as I would be well prepared & $(21.7)$ & $(27.5)$ & $(25.3)$ & $(18.7)$ & $(6.9)$ & $(1.207)$ \\
\hline I would like to have one services company's offer before & 246 & 291 & 124 & 31 & 5 & 1.935 \\
to aspire to have a dream offer & $(35.3)$ & $(41.8)$ & $(17.8)$ & $(4.4)$ & $(.7)$ & $(0.877)$ \\
\hline
\end{tabular}

Note: Figures in parenthesis are percentage and figures in italics within parenthesis represent standard deviation

Table 4.1 shows the responses of the students on certain questions pertaining to the campus recruitment process. 73 per cent of the respondents agree that having multiple companies in one placement slot would give them an opportunity to choose a company of their choice. More than 60 per cent of them say that they would select a company after getting information about the company. There was equal level of agreement / disagreement to have the campus recruitments in the last semester. 77.1 per cent of the respondents would like to have an IT services company's offer before they get selected in a dream company. Dream company is termed as core engineering company or a software company that offers more than INR 4 lakhs per annum.

Table 4.2 shows the students perception on choice of dream company offer over a software services company offer.

Table 4.2. Choice of dream company offer over software services company offer

\begin{tabular}{|l|c|c|c|}
\hline Question & YES & NO & Undecided \\
\hline $\begin{array}{l}\text { I would be more inclined to take a dream company offer (if selected) and leave the software } \\
\text { services company offer which I had earlier }\end{array}$ & 442 & 60 & 195 \\
$(63.4)$ & $(8.6)$ & $(28)$ \\
\hline
\end{tabular}

Table 4.2 shows that 63.4 percent of students would choose a dream company over a software services company, if selected. 28 per cent of them say that they are undecided, this is due to the uncertainties of on-boarding by the dream companies.

The Table 4.3 presents the level of agreement of HR managers in the process relating to campus recruitments.

Table 4.3. HR perceptions on campus recruitment process.

\begin{tabular}{|l|c|c|c|c|c|}
\hline Question & Strongly agree & Agree & Neutral & Disagree & Strongly disagree \\
\hline $\begin{array}{l}\text { It is better to have campus placements in the last } \\
\text { semester }\end{array}$ & $\begin{array}{c}11 \\
(47.7)\end{array}$ & $\begin{array}{c}17 \\
(26.2)\end{array}$ & $\begin{array}{c}11 \\
(16.9)\end{array}$ & $\begin{array}{c}5 \\
(7.7)\end{array}$ & $\begin{array}{c}1 \\
(1.5)\end{array}$ \\
\hline As a HR, I would allow my organization's campus recruit & 19 & 10 & 14 & 14 & 8 \\
to sit for other companies' recruitment & $(29.2)$ & $(15.4)$ & $(21.5)$ & $(21.5)$ & $(12.3)$ \\
\hline Sharing slot gives a student a better choice & 30 & 17 & 7 & 8 & 3 \\
& $(46.2)$ & $(26.2)$ & $(10.8)$ & $(12.3)$ & $(4.6)$ \\
\hline
\end{tabular}

The table 4.3 shows that more than 65 per cent of the HR managers feel that it is better to have campus recruitment process in the final semester. There is no strong agreement by the HR managers on allowing the students who are recruited by their companies to sit for other companies' recruitment. 46.2 per cent of the HR managers strongly agree that the slot sharing gives a student to chance to choose his / her career.

\subsection{Importance of slot sharing using ANOVA}

ANOVA was used to find out if the perceptions of the HR managers and the students on slot sharing concept were the same. 
Table 4.4. Importance of slot sharing using ANOVA

\begin{tabular}{|c|c|c|c|}
\hline Parameter & $\mathrm{N}$ & Mean (SD) & F-Ratio (Sig) \\
\hline Students evaluation & 697 & $2.081(.936)$ & \multirow{3}{*}{$F=0.162(0.687)$} \\
\hline Importance given by HR & 65 & $2.030(1.22)$ & \\
\hline Total & 762 & $2.0768(.963)$ & \\
\hline
\end{tabular}

One way ANOVA results revealed that there was no difference $(F=0.162$; Sig=0.687) in the perception of the two stake holders (HR managers and the students) on the concept of slot sharing. Both the HR managers and students have the same opinion on slot sharing.

\section{Findings and Conclusion}

The study could highlight the perceptions of both the HR managers and students on some of the important components in a campus recruitment process. There is a general perception that students after getting placed tend to lose focus on study in their final semester which gets reflected in their academic grades. Hence, the HR managers feel that it is ideal to have the selection process in the final semester of study. It also enables them to execute the recruitment strategy in an efficient manner. Educational institutions complain that the students are not ready for a placement process before the last semester. They also lose focus on their studies if they get placed before the final semester.

Students are more inclined towards the dream companies than the IT services companies which offer a better salary and job profile. HR managers are not ready to allow the students recruited by them to take part in another company's selection process as it de stabilized their recruitment plan.

Both the HR managers and the students are in favour of having multiple companies in a given slot through the slot sharing process. Slot sharing has given the students to choose the company of their choice and also the institutions to accommodate most of the major recruiters and get benefitted by the branding initiatives done by the corporate on campus.

Employer branding plays an important role in slot sharing. Since the student has a choice of selecting a company in the slot sharing procedure, companies that carry a good brand image on the campuses have an edge over the competitors in attracting the students. Vikram Kapoor (2010) has studied the most important attributes in attracting new talents to the companies and the role of employer branding. A student studying in premier institution in India has multiple choices among the companies that come for campus placements. By leveraging its branding initiatives, a company may focus on the attributes that may attract the students who may decide to choose among the competitors during campus placements.

In the study, the HR managers have given more importance to the soft skill which were captured through a open ended question in the instrument. The institutions should focus on improving the soft skills of the students. The institutions also should cater to the students from rural background in improving their soft skills. Most of the employers give importance to the fundamentals or basic skills (Hesketh, 2000). But the soft skills play an important role as the student may not be able to communicate his basic subject knowledge, if he lacked in the soft skills.

\section{References}

Bottjen Audrey, Cohen Andy (2001), "The benefits of college recruiting”, Journal of Sales \& Marketing Management, Vol.153, No 4, pp. 12

Christopher J. Collins, Cynthia Kay Stevens (2002), "The Relationship Between Early Recruitment-Related Activities and the Application Decisions of New Labor-Market Entrants: A Brand Equity Approach to Recruitment”, Journal of Applied Psychology, Vol. 87, No 6, pp. 1121-1133.

Clarke, M. (2008), "Understanding and managing employability in changing career contexts", Journal of European Industrial Training, Vol. 32, No4, pp. 258-84.

Daniel M. Cable, Mary E. Graham (2000), "The determinants of job seekers' reputation Perceptions", Journal of Organizational Behaviour, Vol. 21, pp.929-947.

Hesketh, A. (2000), "Recruiting an elite? Employers' perceptions of graduate employment and training", Journal of Education and Work, Vol. 13, No.3, pp.245-71.

Jane W. Moy, Sze M. Lee, (2002), "The career choice of business graduates: SMEs or MNCs?", Career Development International, Vol. 7, No 6, pp. 339-347. 
Nasscom : Only $25 \%$ IT graduates readily employable (Online)

Available:http://articles.economictimes.indiatimes.com/2011-04-07/news/29392668_1_engineering-colleges-employability-studynasscom (April 7, 2011)

Ruth R Robbins (1996), "Attitudes and Perceptions of Computer Information Systems students toward Employment Opportunities", Journal of employment counseling, Vol. 33,pp.61-69.

Vikram Kapoor (2010), "Employer Branding: A Study of Its Relevance in India", The IUP Journal of Brand Management, Vol. 7 Nos. 1 \& 2, pp.52-75. 